\title{
A HAIR PIECE: PERSPECTIVES ON THE INTERSECTION OF RACE AND GENDER
}

\author{
Paulette M. Caldwell*
}

\section{Of SMall Beginnings}

\section{A. Rediscovering My Hair}

I want to know my hair again, to own it, to delight in it again, to recall my earliest mirrored reflection when there was no beginning and I first knew that the person who laughed at me and cried with me and stuck out her tongue at me was me. I want to know my hair again, the way I knew it before I knew that my hair is me, before I lost the right to me, before I knew that the burden of beauty-or lack of it-for an entire race of people could be tied up with my hair and me.

$I$ want to know my hair again, the way I knew it before I knew Sambo and Dick, Buckwheat and Jane, Prissy and Miz Scarlett. Before I knew that my hair could be wrong-the wrong color, the wrong texture, the wrong amount of curl or straight. Before hot combs and thick grease and smelly-burning lye, all guaranteed to transform me, to silken the coarse, resistent wool that represents me. I want to know once more the time before I denatured, denuded, denigrated, and denied my hair and me, before I knew enough to worry about edges and kitchens and burrows and knots, when I was still a friend of water-the rain's dancing drops of water, a swimming hole's splashing water, a hot, muggy day's misty invisible water, my own salty, sweaty, perspiring water.

When will I cherish my hair again, the way my grandmother cherished it, when fascinated by its beauty, with hands carrying centuries-old secrets of adornment and craftswomanship, she plaited it, twisted it, cornrowed it, finger-curled it, olive-oiled it, on the growing moon cut and shaped it, and wove it like fine strands of gold inlaid with semiprecious stones, coral and ivory, telling with my hair a lost-found story of the people she carried inside her?

Mostly, I want to love my hair the way I loved hers, when as granddaughter among grandsons I stood on a chair in her room-her kitchenbed-living-dining room-and she let me know her hair, when I combed

\section{Copyright (C) Paulette M. Caldwell 1991.}

* Professor of Law, New York University. An earlier version of this Essay was presented to the first Critical Race Theory Workslop, sponsored by the Institute for Legal Studies, University of Wisconsin Scliool of Law, July 1989. My thanks to the participants in that workshop. Thanks also to many others, including menibers of the Northeast Corridor Collective of Black Woinen Law Professors, Eric Steele, Esq., Jacqueline Berrien, Esq., and to researcli assistants Sanya Hill and Gilda Williams, New York University Law School classes of 1988 and 1990, respectively. 
and patted it from the crown of her head to the place where her neck folded into her shoulders, caressing steel-gray strands that framed her forehead before falling into the soft, white, cottony temples at the border of her cheekbones.

Cotton. Cotton curled up in soft, fuzzy puffballs around her face. Cotton pulled out and stretched on top of her head into Sunday pompadours. Cotton, like the cotton blooming in August in her tiny cotton field. Cotton, like the cotton that filled the other room in her house-the cotton room-the storehouse for September's harvest, a cradle to shield her pickings from wind and rain, to await baling and ginning and cashing in. Cotton, which along with a cow, a pig and a coop of chickens, allowed her to eke out a husband-dead, children-gone independence in some desolate place, trapped in the bowels of segregation. Here, unheard, unseen, free, she and her beauty and her hair could not be a threat to anyone.

\section{B. On Being the Subject of a Law School Hypothetical}

The case of Rogers $v$. American Airlines ${ }^{1}$ upheld the right of employers to prohibit categorically the wearing of braided hairstyles in the workplace. The plaintiff, a black woman, argued that American Airline's policy discriminated against her specifically as a black woman. In effect, she based her claim on the interactive effects of racial and gender discrimination. The court close, lowever, to base its decision principally on distinctions between biological and cultural conceptions of race. More importantly, it treated the plaintiff's claims of race and gender discrimination in the alternative and independent of each other, thus denying any interactive relationship between the two.

Although Rogers is the only reported decision that upholds the categorical exclusion of braided hairstyles, ${ }^{2}$ the prohibition of such styles in the workforce is both widespread and longstanding. Protests surrounding recent cases in Washington, D.C. sparked national media attention. Nearly fifty women picketed a Hyatt Hotel, and black political leaders threatened to boycott hotels that prohibit black women from wearing braids. ${ }^{3}$ Several employees initiated legal action by filing complaints with federal or local fair employment practices agencies; most cases were set-

1. 527 F. Supp. 229 (S.D.N.Y. 1981).

2. Rogers relied on Carswell v. Peachford Hosp., 27 Fair Empl. Prac. Cas. (BNA) 698 (N.D. Ga. 1981) (1981 WL 224). In Carswell, the employer discharged the plaintiff for wearing beads woven into a braided hairstyle. The prohibition apphied to jewelry and other items and was justified by safety precautions for employees working in a hospital for psychiatric and substance-abusing patients. Significantly, the court noted that the hospital did not categorically prohibit the wearing of either braided or Afro hairstyles.

3. See Shipp, Braided Hair Style At Issue in Protests Over Dress Codes, N.Y. Times, Sept. 23, 1987, at C14, col. 1. 
tled shortly thereafter. No court has yet issued an opinion that controverts Rogers.

I discovered Rogers while reading a newspaper article describing the actual or threatened firing of several black women in metropolitan Washington, D.C. solely for wearing braided hairstyles. ${ }^{4}$ The article referred to Rogers but actually focused on the case of Cheryl Tatum, who was fired from her job as a restaurant cashier in a Hyatt Hotel under a company policy that prohibited "extreme and unusual liairstyles."s

The newspaper description of the Hyatt's grooming policy conjured up an image of a ludicrous and outlandishly-coiffed Cheryl Tatum, one clearly bent on exceeding the bounds of workplace taste and discipline. But the picture that accompanied the article revealed a young, attractive black woinan whose hair fell neatly to her shoulders in an all-American, common, everyday pageboy style, distinguished only by the presence of tiny braids in lieu of single strands of hair.

Whether motivated by politics, ethnic pride, health, or vanity, I was outraged by the idea that an employer could regulate or force me to explani something as personal and private as the way that I groon $m y$ hair. I resented the implication that I could not be trusted to choose standards appropriate for the workplace ${ }^{6}$ and that my right to work could be conditioned on my disassociation with my race, gender, and culture. Mostly, I nuarveled with sadness that something as simple as a black woman's hair continues to threaten the social, political, and economic fabric of American life.

My anger eventually subsided, and I thought little more about Rogers until a student in my course in Employınent Discrimination Law

4. Shipp, supra note 3 , at $\mathrm{Cl}$.

5. Braided hairstyles are often prohibited under management interpretations of general groouning code provisions. However, according to Washington, D.C. attorney Eric Steele, many companies have adopted written policies that specifically prohibit braided hairstyles.

6. In Carroll v. Talman Fed. Sav. \& Loan Ass'n, 604 F.2d 1028 (7th Cir. 1979), the plaintiff was suspended for refusing to comply with a policy that required fenale tellers, office, and managerial employees to wear a uniform selected by the employer, whereas men in the same positions were allowed to wear normal business attire of their own clioosing. The employer had dispensed with a coinparable requirement for uniforms applicable to male einployees from 1958 to 1969. The employer's counsel sought to justify the limitation on female employees, stating that, although the einployer trusted the business judgment of its female employees,

the selection of attire ... on the part of women is not a inatter of business judgment. It is a matter of taste, a matter of what the other women are wearing, what fashion is currently.

... Somehow, the woinen who lave excellent business judgment ... tend to follow those [fashions] and they don't seem to equate that with a matter of business judgment.

Id. at 1033. On the last Tuesday of every month (when uniforms were being cleaned) and during Christnas week, women employees were exempted from the uniform requirement. (These days were referred to by the employer as "glamour days.") The employer admitted that on these days wonnen einployees never wore improper business attire. Id. 
asked me after class to explain the decision. I promised to take up the case when we arrived at that poimt in the seinester where the issues raised by Rogers fit most naturally in the development of antidiscrimination law.

Several weeks passed, and the student asked about Rogers again and again (always privately, after class); yet I always put off answering her until soine point later in the semester. After all, hair is such a little thing. Finally, while participating in a class discussion on a completely unrelated topic, the persistent one's comments wandered into the forbidden area of braided-hair cases. As soon as the student realized she had pubhicly introduced the subject of braided hair, she stopped in mid-sentence and covered her mouth in einbarrassment, as if she had spoken out of turn. I was finally forced to confront what the student had obviously sensed in her einbarrassinent.

I had avoided private and public discussions about braided hair not because the student had asked her questions at the wrong point in the semester. Nor had I avoided the subject because cases involving einployer-mandated hair and groommg standards do not illustrate as well as other cases the presence of deeply-ingrained myths, negative images, and stercotypes that operate to define the social and economic position of blacks and women. I had carefully evaded the subject of a black woman's hair because I appeared at each class ineeting wearing a neatlybraided pageboy, and I resented being the unwitting object of one in thousands of law school hypotheticals.

\section{Why Would Anyone Want to Wear Their Hair That Way?7}

Discussing braided hair styles with students did not threaten me in places where I had becoine most assured. I was personally at ease in my professionalism after a decade of law practice and nearly as inany years as a law professor. I had lost-or becoine nore successful in denyingany discomfort that I once may have experienced in discussing issues of race and gender in the too few occasions in the legal profession devoted to their exploration. I had even begun to smart less when confronted with my inability to change being the only, or one of inevitably too few,

7. According to Cheryl Tatum, the Hyatt's personnel manager, a woman, said: "l can't understand why you would want to wear your hair like that anyway. What would our guests think if we allowed you all to wear your hair like that?" Shipp, supra note 3, at C14. Employers often rely on "customer preference" to justify the inposition of certain requirements on employees or to restrict, on the gronnds of race or sex, the persons who can occupy certain jobs. This justification typically amounts to nothing more than the expression of the preferences of the employer or a subterfuge for the exploitation of the images of employees for ccononic advantage. See Binder, Sex Discrimination in the Airline Industry: Title VII Flying High, 59 CALIF. L. REV. 1091 (1971); see also infra notes 63-71 and accompanying text. 
blacks on the faculty of a traditionally white law school. But I was not prepared to adopt an abstract, dispassionate, objective stance to an issue that so obviously affected me personally; nor was I prepared to suffer publicly, through intense and passionate advocacy, the pain and outrage that I experience each time a black woman is dismissed, belittled, and ignored simply because she challenges our objectification.

Sliould I be put to the task of choosing a logical, credible, "legitiinate," legally-sympathetic justification out of the many reasons that may have motivated me and otler black women to braid our own hair? Perhaps we do so out of concern for the lealtl of our hair, which many of us risk losing permanently after years of chemical straighteners; or perhaps because we fear that the entry of chemical toxins into our bloodstreams through our scalps will damage our unborn or breastfeeding children. Soune of us clioose the positive expression of ethnic pride not only for ourselves, but also for our children, many of whoin learn, despite all of our teachings to the contrary, to reject association with black people and black cnlture in search of a keener nose or bluer eye. Many of us wear braids in the exercise of private, personal prerogatives taken for granted by women who are not black.

Responding to student requests for explanations of cases is a regular part of the profession of law teaching. I was not required, therefore, to express or justify the reasons for my personal decision to braid my lair in order to discuss the application of employment discrimination laws to braided laairstyles. But by legitimizing the notion that the wearing of any and all braided hairstyles in the workplace is unbusinesslike, Rogers delegitimized me and my professionalism. I could not think of an answer that would be certain to observe traditional boundaries in academic discourse between the personal and the professional.

The persistent student's embarrassed questioning and my obfuscation spoke of a woman-centered silence: She, a white woinan, had asked me, a black woman, to justify my hair. ${ }^{8}$ Slie compelled me to account for the presence of legal justifications for my smiultaneously "perverse visibility and convenient invisibility." Slie forced me and the rest of the class to acknowledge the souls of women who live by the circumscrip-

8. I know that the student intended no harm toward ine. She, too, was disturbed by Rogers. She had come to law school later in life than inany of her classinates and was already experiencing the prejudices of the labor inarket related to the intersection of gender and age. She seemed to sense that something in the underlying racism and sexism in Rogers would ultimately affeet her in a personal way.

9. McKay, Black Woman Professor-White University, 6 WoMEN's STUD. INT'L. F. 143, 144 (1983). 
tions of coinpeting beliefs about white and black womanliood and in the interstices of racisin and sexism.

Our silence broken, the class inoved beyond hierarchy to a place of honest collaboration. Turning to Rogers, we explored the question of our ability to coinprehend through the inedium of experience ${ }^{10}$ the way in whicli a black woman's liair is related to the perpetuation of social, political, and econonic domination of subordinated racial and gender groups; we asked wliy issues of experience, culture, and identity are not the subject of explicit legal reasoning. This Essay relates soine of what we have learned and wliat we need to know.

Hair seems to be such a little thing. Yet it is the little things, the small everyday realities of life, thrat reveal the deepest meanings and values of a culture, give legal theory its grounding, and test its legitimacy.

\section{To Choose Myself: INTERLocking Figurations IN THE CONSTRUCTION OF RACE AND GENDER}

\section{A. A Black Woman's Hair, A Black Woman's Place}

SUNDAY. School is out, my exams are graded, and I have unbraided my hair a few days before my appointment at the beauty parlor to have it braided again. After a year in braids, my hair is healthy again: long and thick and cottony soft. I decide not to french roll it or twist it or pull it into a ponytail or bun or cover it with a scarf. Instead, I comb it out and leave it natural, in a full and big "Angela Davis" afro style. I feel full and big and regal. I walk the three blocks from my apartment to the subway. I see a white male colleague walking in the opposite direction and I wave to him from across the street. He stops, squints his eyes against the glare of the sun and stares, trying to figure out who has greeted him. He recognizes me and starts to cross over to my side of the street. I keep walking, fearing the possibility of his curiosity and needing to be relieved of the strain of explanation.

MONDAY. My hair is still unbraided, but I blow it out with a hair dryer and pull it back into a ponytail tied at the nape of my neck before I go to the law school. I enter the building and run into four white female colleagues on their way out to a white female lunch. Before I can say hello, one of them blurts out, "It IS weirdl" Another drowns out the first: "You look so young, like a teenagerl" The third invites me to join them for lunch while the fourth stands silently, observing my hair. I mumble some excuse about lunch and, interject, almost apologetically,

10. The experience of racist, public degradation on account of hair texture is not exclusive to black women. Since I began teaching Rogers and issues that relate to the intersection of race and gender, many white women students have told me (always privately) that they lave been disparaged and have suffered low self-esteem because the texture of their hair is too close to that of a black woman. This disparagement and public ridicule typically begins for them near the age of puberty, when issues of beauty, sexuality, and desirability are of simgular importance. 
that I plan to get my hair braided again the next day. When I arrive at my office suite and run into the white male I had greeted on Sunday, I realize immediately that he has told the bunch on the way to lunch about our encounter the day before. He mutters something about how different I look today, then asks me whether the day before I had been on my way to a ceremony. He and the others are generally nice colleagues, so I half-smile, but say nothing in response. I feel a lot less full and big and regal.

TUESDAY. I walk to the garage under my apartment building, again wearing a big, full "Angela Davis" afro. Another white male colleague passes me by, not recognizing me. I greet him and he smiles broadly saying that he has never seen me look more beautiful. I smile back, continue the chit chat for a moment more and try not to think about whether he is being disingenuous. I slowly get into my car, buckle up, relax, and turn on the radio. It will take me about forty-five minutes to drive uptown to the beauty parlor, park my car, and get something to eat before beginning the long hours of sitting and braiding. I feel good, knowing that the braider will be ecstatic when she sees the results of her healing handiwork. I keep my movements small, easy, and slow, relishing in a rare, short morning of being free.

\section{B. When Race and Gender Intersect}

My initial outrage notwithstanding, Rogers is an unremarkable decision. Courts generally protect employer-mandated hair and dress codes, and they often accord the greatest deference to codes that classify individuals on the basis of socially-conditioned rather than biological differences.11 And although Rogers rests on one line of authority without acknowledging the existence of another, grooming codes are governed by decisional law that clearly lacks conceptual coherence. ${ }^{12}$ All in all, such cases are generally considered only marginally significant in the battle to seeure equal employment rights.

But Rogers is regrettably unremarkable in an important respect. It rests on suppositions that are deeply imbedded in American cultureassumptions so entrenched and so necessary to the maintenance of interlocking, mterdependent structures of domination that their mythological bases and political functions have become invisible, especially to those to whom their existence is most detrimental. Rogers proceeds from the preinise that, although racism and sexism share much in common, they are nonetheless fundamentally unrelated phenomena-a proposition proved false by history and contemporary reality. Racism and sexism

11. But see infra text accompanying note 66 for a discussion of the extent to which prejudice and discrimination are motivated by cultural, rather than biological, differences among groups.

12. 1 R. Richards, C. Sullivan \& M. ZimMER, EMPLOYMENT DisCRimination $\$ 8.5$, at $349-53$ (1988). 
are interlocking, mutually-reinforcing components of a system of dominance rooted in patriarchy. No significant and lasting progress in combatting either can be made until this interdependent aspect of their relation is acknowledged, and until the perspectives gained froin considering their imteraction are reflected in legal theory and public policy.

Black women are the immediate, although not exclusive, plyysical and material representation of the mtersection of race and gender. ${ }^{13}$ Progress against racism and sexism requires im addition, therefore, not only an eradication of negative stereotypes about black womanhood and their associated belravioral consequences, but also a recognition that theories of legal protection that affect the material circumstances of black women are not marginal to theories regarding race or gender, but ratlier are central to both. ${ }^{14}$

Rogers is an exeinplar of employment discrimination cases that imvolve black women's physical image, negative stereotypes of black womanhood, and the intersection of race and gender. The assumptions underlying Rogers also appear in other areas, mcluding those in which facile conflations of biology and culture combine with the intersection of race and gender to condition reproductive and lifestyle choices arguably more fundainental than those of hairstyle. ${ }^{15}$

\section{The Limitations of the Assumptions of Race-Sex Correspondence and Independence}

There is clearly a legal assumption of a race-sex correspondence or of a race-sex parallel. Women and blacks share a common history im terins of some elements of their legal status, although actual differences in their social status and attitudes toward them were, and are, substan-

13. See infra text accompanying notes $97-99$ for the effects of race-gender intersection on black men and white women.

14. Questions arising at the intersection of race and gender have only recently been addressed by legal scholars. See generally Austin, Sapphire Boundl, 1989 WIs. L. Rev. 539; Crenshaw, Demarginalizing the Intersection of Race and Sex: A Black Feminist Critique of Antidiscrimination Doctrine, Feminist Theory and Antiracist Politics, 1989 U. CHI. Legal F. 139; Harris, Race and Essentialism in Feminist Legal Theory, 42 STAN. L. REv. 581 (1990). This late attention to the intersection of race and gender is not unrelated to the low numbers, and experiences of, black women professors in the legal acadeny. For an analysis of the relationship between the experiences of black women academics and the development of black feminist thought, see Collins, The Social Construction of Black Feminist Thought, in BLACX WOMEN IN AMERICA 304 (1988).

15. See infra text accompanying notes 29-32. The decision whether to characterize a dispute as involving grooming or solne arguably more fundamental right has significant consequences under antidiscrimination law. The characterization as "grooming" often signals a trivialization of the claim and a conclusion that no legally-protected employinent and economic rights are involved. See, e.g., Craft v. Metromedia, Inc., 766 F.2d 1205 (8th Cir. 1985). But the aesthetic order of a society sets the norms of beauty and acceptability of the dominant group as the standard; this aesthetic order is used, in turn, to justify the superior social and economic position of the dominant group. 
tial. For many purposes, the law does and should treat racism and sexisin as equivalent forms of bias, and theories and reinedies developed in considering one form should ordinarily extend to the other. ${ }^{16}$ This assumption has clearly influenced the development of legal theory concerning race and gender. ${ }^{17}$ Identifying parallels serves an important heuristic function and provides a powerful tool to conceptualize and mobilize resistance to inequality.

Correlative to the assumption of race-sex correspondence, there exists an equally powerful assumption of race-sex independence or distinctiveness. ${ }^{18}$ Also rooted in American history, particularly in the politics of emancipation and suffrage, this assumption has contemporary manifestations in the existence of distinct political inovements aganist racisin and sexisin, the developinent of social pohicy along exclusively gender or race lines, and the legal conceptualization of distinct approaches to issues of race and gender. ${ }^{19}$

Like race-sex correspondence, the existence of a belief in race-sex distinctiveness is not itself a problein; it can serve important functions in the developinent of comprehensive legal theory on questions of race and gender. Considering actual or apparent differences between race and gender may lead to important insights, which in turn may assist in conceptualizing new approaches to challenging oppression based on either. And if, through the correspondence of race and gender, we intend to treat the two equally, and are committed to avoiding the developinent of hierarchies of oppression or notions of essentialism, ${ }^{20}$ then the intuitions derived from treating thein separately under a theory of race-sex inde-

16. A classic statement of the race-sex parallel appears in Gunnar Myrdal's study of American race relations. See Myrdal, A Parallel to the Negro Problem, in AN AMERICAN DilemMA 1073-78 (1944); see also Hacker, Women as a Minority Group, 30 Soc. ForCES 60 (1951); Johnston \& Knapp, Sex Discrimination By Law: A Study in Judicial Perspective, 46 N.Y.U. L. REv. 675 (1971); Murray, The Negro Woman's Stake in the Equal Rights Amendment, 6 HaRv. C.R.-C.L. L. REV. 253 (1971); Note, Sex Discrimination and Equal Protection: Do We Need a Constitutional Amendment?, 84 HARV. L. REV. 1499 (1971).

17. See, e.g., Frontiero v. Richardson, 411 U.S. 677 (1973); B. BABCock, A. FreedMAN, E. Norton \& S. Ross, SEX DisCrimination AND THE LAw: CAUSES AND REMEDies $89-92$ (1975).

18. Indeed, one could argue that the concentration on the race-sex parallel arises in part from an implicit assumption about the differences between race and gender.

19. See generally King, Multiple Jeopardy, Multiple Consciousness: The Context of a Black Feminist Ideology, in BLACK WOMEN IN AMERICA, supra note 14, at 265; Singleton, Race and Gender in Feminist Theory, SAge: Scholably J. on Black WomeN, Summer 1989, at 12-17.

20. But see Harris, supra note 14 , at 588-89 (critiquing the essentialism within feuminism and the essentialism of gender, and suggesting the problems that can arise from the assumption of a difference between race and gender). 
pendence will ultimately serve both. Any starting point will suffice if our objective is to end domination based on race, gender, or both..1

Problems arise in the development of legal theory and social policy when the possibility of other relationships between race and gender, such as intersection, are not considered. Black women's issues "ship through the cracks" of legal protection, ${ }^{22}$ and the gender components of racism and the race components of sexism remain hidden. ${ }^{23}$

The interactive relationship between race and gender is unmistakable. Its existence flows factually and logically from an examination of the structure of dominance-historically and contemporarily-and the stereotypes, myths, and images about race and gender, and in particular black women, that sustain it. It is perplexing, therefore, that those committed to eliminating dominance based on race or gender, or both, contimually fail to acknowledge or derive hiberating strategies based on the fact of race-sex interaction. ${ }^{24}$

Cases arising under einployinent discrimination statutes illustrate both the operation in law and the effect on the development of legal theory of the assumptions of race-sex correspondence and difference. These cases also demonstrate the absence of any consideration of either race-sex interaction or the stereotyping of black woinanhood. Focusing on cases that mvolve black female plaintiffs, at least three categories einerge.

In one category, courts have considered whether black woinen may represent themselves or other race or gender discriminatees. Some cases deny black women the right to claim discrimination as a subgroup distinct from black men and white women. ${ }^{25}$ Others deny black woinen the right to represent a class that imcludes white women in a suit based on sex discrimination, on the ground that race distinguishes thein. ${ }^{26}$ Still other cases prohibit black women from representing a class in a race discrimination suit that includes black men, on the ground of gender differ-

21. But see King, supra note 19, at 268 (suggesting that a part of the function of race-sex parallelism is to mask substantive, if not qualitative, differences between racism and sexism as well as to make the experiences of black women invisible).

22. See Slipping Through the Cracks: The Status of Black Women (J. Malveaux \& M. Simms eds. 1987).

23. See H. CARBY, Slave and Mistress: Ideologies of Womanhood under Slavery, in RECoNSTRUCTING WOMANHOOD 20 (1987).

24. See King, supra note 19 , at $276-86$ (discussing intraracial politics and politics among women).

25. See, e.g., DeGraffenreid v. General Motors Assembly Div., 413 F. Supp. 142, 145 (E.D. Mo. 1976) (Title VII did not create a new sub-category of "black women" witl standing independent of black males).

26. See, e.g., Moore v. Hughes Helicopter, Inc., 708 F.2d 475, 480 (9th Cir. 1983) (certified class includes only black females, as plaintiff black female inadequately represents white feinales' interests). 
ences. ${ }^{27}$ These cases demonstrate the failure of courts to account for race-sex intersection, and are premised on the assumption that discrimination is based on either race or gender, but never both. ${ }^{28}$

A second category of cases concerns the interaction of race and gender in determining the limits of an employer's ability to condition work on reproductive and inarital choices associated with black women. ${ }^{29}$ Several courts have upheld the firing of black women for becoming pregnant while unmarried if their work involves association with childrenespecially black teenage girls. These decisions rest on entrenched fears of and distorted images about black feinale sexuality, stigmatize single black mothers (and by extension their children) and reinforce "culture of poverty" notions that blame poverty on poor people themselves. ${ }^{30}$ They also reinforce the notion that the problems of black families are attributable to the deviant and dominant roles of black women ${ }^{31}$ and the idea that racial progress depends on black female subordination. ${ }^{32}$

A third category concerns black women's physical images. These cases involve a variety of mechanisms to exclude black women from jobs that involve contact with the public-a tendency particularly evident in traditionally female jobs in which employers place a preımum on female

27. See, e.g., Payne v. Travenol, 673 F.2d 798, 810-12 (5th Cir. 1982) (interests of black female plaintiffs substantially conflict with interests of black males, simce females sought to prove that males were promoted at females' expense notwithstanding the court's finding of extensive racial discrimination).

28. See generally Crenshaw, supra note 14.

29. See Chambers v. Girls Club of Omaha, 834 F.2d 697 (8th Cir. 1987); see also Austin, supra note 14.

30. The culture of poverty notion is rooted in the works of Daniel Patrick Moynihan. See, e.g., P. Moynihan, The Negro Family: A Case for National Action, in The Moynihan Report and the Politics of Controversy 39-124; see also E. Frazier, The Negro in the United States (1968).

31. Traditional analyses of the black family compare it to middle-class white families-thereby, in the face of longstanding oppression, emphasizing its weaknesses rather than focusing on its strengths. See E. FrazIER, supra note 30, at 300-02, 328-33. Such studies focus on the attitudes and behavior of blacks as the source of difficulty in black family structure and fail to account for the structural effects of oppression or to propose policies that would alleviate the effects of oppression. See generally A. Billingsley, BlACK FAMILIES IN WhITE AMERICA 14-15, 122-24, 131-37 (1968). Underlying these traditional analyses of the black family are myths about the existence of a black female matriarchy and the detrimental effects that this matriarchy has on blacks generally and on black males in particular. See Staples, The Myth of the Black Matriarchy, in THE BLACK WoMAN CROSS-Culturaliy 335-48 (F. Steady ed. 1981). These myths contribute to the fiction that black women are doubly advantaged in relation to black men, and to the assumption that racial progress for blacks depends on the subordination of black women. See Jackson, Black Women in a Racist Society, in RACISM AND MENTAL HEALTH 185, 254 (1973). Recently, ideas regarding black women as negative role models have appeared in the formulation of educational policy directed toward reducing black male school dropout and inearceration rates.

32. In DeGraffenreid v. General Motors Assembly Div., 413 F. Supp. 142 (E.D. Mo. 1976), the court obviously feared that black women would be doubly-advantaged by a coordination of both the race and gender components of their claims. 
attractiveness-including a subtle, and often not so subtle, einphasis on female sexuality. The latter two categories sometimes involve, in addition to the intersection of race and gender, questions that concern the interaction of race, gender, and culture.

The failure to consider the imphications of race-sex interaction is ouly partially explained, if at all, by the historical or contemporary developinent of separate pohtical inoveinents against racism and sexism. Rather, this failure arises froin the inability of pohtical activists, policymakers, and legal theorists to grapple with the existence and pohtical functions of the coinplex of inyths, negative images, and stereotypes regarding black womanhood. ${ }^{33}$ These stereotypes, and the culture of prejudice that sustains thein, exist to define the social position of black women as subordinate on the basis of gender to all inen, regardless of color, and on the basis of race to all other woinen. These negative images also are indispensable to the inaintenance of an interlocking systein of oppression based on race and gender that operates to the detriment of all woinen and all blacks. Stereotypical notions about white woinen and black men are not only developed by comparing thein to white inen, but also by setting them apart froin black women.

\section{The Rogers Opinion}

The Rogers decision ${ }^{34}$ is a classic exainple of a case concerning the physical image of black woinen. Renee Rogers, whose work for American Airlines involved extensive passenger contact, claimed that American's prohibition of braided hairstyles in certain job classifications discriminated against her as a woinan in general, and as a black woinan in particular. ${ }^{35}$ The court did not attempt to limit the plaintiff's case by forcing her to proceed on either race or gender grounds, ${ }^{36}$ nor did it create a false hierarchy between the two bases by treating one as grounded in statutory law and the other as a "plus" factor that would explain the

33. See, e.g., H. CARBY, supra note 23, at 27.

34. Rogers v. American Airlines, Inc., 527 F. Supp. 229 (S.D.N.Y. 1981).

35. Id. at 231. Rogers sued under the thirteenth amendment, 42 U.S.C. $\$ 1981$ (1988), and Title VII of the Civil Rights Act of 1964, 42 U.S.C. $\$ \S 2000 \mathrm{e}$ (1988). The court disposed of the thirteenth amendment claim on the ground that the amendment prohibits practices that constitute badges and incidents of slavery. Unless the plaintiff could show that she did not have the option to leave her job, her claim could not be maintained. Rogers, 527 F. Supp. at 231. The court also noted that the Title VII and section 1981 claims were indistinguishable in the circumstances of the case and were, therefore, treated together. Id.

36. For an example of a case refusing to allow a plaintiff to proceed as a "black woman," an independent sub-category protected by Title VII, see DeGraffenreid v. General Motors Assembly Div., 413 F. Supp. 142 (E.D. Mo. 1976). The district court's limitation on the ability of black women to sue on the basis of race and sex was lifted on appeal. DeGraffenreid v. General Motors Assembly Div., 558 F.2d 480 (8th Cir. 1977). 
application of law to a subgroup not technically recognized as a protected group by law. ${ }^{37}$ The court also appeared to recognize that the plaintiff's claim was not based on the cumulative effects of race and gender. ${ }^{38}$

However, the court treated the race and sex claims in the alternative only. This approach reflects the assumption that racism and sexism always operate independently even when the claimant is a member of both a subordinated race and a subordinated gender group. The court refused to acknowledge that American's policy need not affect all women or all blacks in order to affect black woinen discriminatorily. By treating race and sex as alternative bases on which a claim might rest, the court concluded that the plaintiff failed to state a claim of discrimination on either ground. The court's treatment of the issues made this resnlt imevitableas did its exclusive rehance on the factors that it insisted were dispositive of cases involving employee grooming or other inlage preferences.

The distmct history of black women dictates that the analysis of discrimination be appropriately tailored in interactive claims to provide black women with the saine protection available to other individuals and groups protected by antidiscrimination law. The Rogers court's approach permitted it to avoid the essence of overlapping discrimination against black women, and kept it from applying the basic elements of antidiscrimination analysis: a focus on group history; identification of recurring patterns of oppression that serve over time to define the social and economic position of the group; analysis of the current position of the group in relation to other groups in society; and analysis of the employment practice in question to determine whether, and if so, how, it perpetuates individual and group subordination. ${ }^{39}$

37. See Jefferies v. Harris County Community Action Assoc., 615 F.2d 1025, 1032-34 (5th Cir. 1980) (permitting black women to sue on grounds of race and sex, albeit on a "plus" theory that erroneously treats one basis as grounded in the language of Title VII describing protected groups and the other as implied to protect a subgroup not specifically protected by law). This approach overlooks the fact that both race and sex are protected categories authorized by law. The "plus" theory is generally applied to cases in which an employer discriminates against some, but not all, women or men, and does so on the basis of a characteristic in addition to gender which courts consider of legal significance (e.g., discrimination against married women or against mothers). Id. at 1033.

38. Cumulative effects of race and gender may be involved, for example, im a claim arguing that a paper and pencil test (which excludes disproportionate numbers of blacks) and a height or strength requirement (which excludes disproportionate numbers of women) combime to exclude statistically significant numbers of black women even though black men and white women are not similarly affected. See generally Shoben, Compound Discrimination: The Interaction of Race and Sex in Employment Discrimination, 55 N.Y.U. L. REv. 793, 793-98 (1980) (discussing what the author terms "compound discrimination").

39. See L. Thurow, The Zero-Sum Society: Discrimination and the Possibilities FOR ECONOMIC CHANGE 184-89 (1980). Courts should follow this approach in any case in which a 
The court gave three principal reasons for dismissing the plaintiff's claim. First, in considering the sex discrimination aspects of the claim, the court disagreed with the plaintiff's argument that, in effect, the apphication of the coinpany's grooming policy to exclude the category of braided hairstyles froin the workplace reached only woinen. Rather, the court stressed that American's poticy was even-handed and applied to men and women alike.40 Second, the court emphasized that American's grooming policy did not regulate or classify employees on the basis of an immutable gender characteristic. ${ }^{41}$ Finally, American's poticy did not bear on the exercise of a fundamental right. ${ }^{42}$ The plaintiff's racial discrimination claim was analyzed separately but dismissed on the saine grounds: neutral application of American's anti-braid policy to all races and absence of any mipact of the poticy on an immutable racial characteristic or of any effect on the exercise of a fundamental right.

The court's treatment of culture and cnltural associations in the racial context bears close examination. It carefully distinguished between the phenotypic and cnltural aspects of race. First, it rejected the plaintiff's analogy between all-braided and Afro or "natural" hairstyles. Stopping short of concluding that Afro hairstyles might be protected under all circumstances, the court held that "an all-braided hairstyle is a different matter. It is not the product of natural hair growth but of artifice."43 Second, in response to the plaintiff's argument that, like Afro hairstyles, the wearing of braids reflected her choice for ethnic and cultural identification, the court again distinguished between the immutable aspects of race and characteristics that are "sociocnlturally associated with a particular race or nationality." 44 However, given the variability of so-called immutable racial characteristics such as skin color and hair texture, it is difficult to understand racisin as other than a complex of historical, sociocultural associations with race.

The court conceived of race and the legal protection against racisin almost exclusively in biological terins. Natural hairstyles-or at least some of thein, such as Afros ${ }^{45}$-are permitted because hair texture is immutable, a matter over which individuals have no choice. Braids, however, are the products of artifice-a cultural practice-and are therefore mutable; i.e., the result of choice. Because the plaintiff could have

black woman alleges discrimination on race and sex grounds and the court determimes that compound discrimination is not imvolved. See Shoben, supra note 38.

40. Rogers, 527 F. Supp. at 231.

41. Id.

42. Id.

43. Id. at 232 .

44. Id.

45. See infra note 59 (discussing other natural hairstyles). 
altered the all-braided liairstyle in the exercise of lier own volition, American was legally authorized to force that choice upon her.

In support of its view that the plaintiff had failed to establish a factual basis for her claim that American's policy had a disparate impact on black women, thus destroying any basis for the purported neutral application of the policy, the court pointed to American's assertion that the plaintiff had adopted the prohibited hairstyle only shortly after it had been "popularized" by Bo Derek, a white actress, in the film "10."46 Notwithstanding the factual maccuracy of American's claim, and notwithstanding the implication that there is no relationship between braided hair and the culture of black women, the court assumed that black and white women are equally motivated (i.e., by the movies) to adopt braided hairstyles.

Wherever they exist in the world, black women braid their hair. They have done so in the United States for inore than four centuries. African im origin, the practice of braiding is as American-black American -as sweet potato pie. A braided hairstyle was first worn in a nationally-televised inedia event in the Umited States-and in that sense "popularized"- by a black actress, Cicely Tyson, nearly a decade before the inovie "10."47 More importantly, Cicely Tyson's choice to popularize (i.e., to "go public" with) braids, like her choice of acting roles, was a political act nrade on her own behalf and on behalf of all black wonien. ${ }^{48}$

The very use of the term "popularized" to describe Bo Derek's wearing of braids-in the sense of rendering suitable to the najorityspecifically subordinates and nakes invisible all of the black wornen who for centuries have worn braids in places where they and their hair were not overt threats to the American aesthetic. The great inajority of such women worked exclusively in jobs where their racial subordination was clear. They were never permitted in any affirmative sense of the word any choice so closely related to personal diginty as the choice-or a range of choices-regarding the grooming of their hair. By virtue of their subordination-their clearly defined place in the society-their choices were simply ignored.

The court's reference to Bo Derek presents us with two conflicting images, both of which subordinate black women and black culture. On the one hand, braids are separated fron black culture, and, by imphication are said to arise froin whites. Not only do blacks contribute nothing

46. Rogers, 527 F. Supp. at 232.

47. Tyson is most noted for her roles in the film Sounder (20th Century Fox 1972) and in the television special The Autobiography of Miss Jane Pitman (CBS Television Broadcast, Jan. 1974).

48. Her work is political in the sense that she selects roles that celebrate the strength and dignity of black women and avoids roles that do not. 
to the nation's or the world's culture, they copy the fads of whites. On the other hand, whites make fads of black culture, which, by virtue of their popularization, become-like all "pop"-disposable, vulgar, and without lasting value. Braided hairstyles are thus trivialized and protests over them made ludicrous. ${ }^{49}$

To narrow the concept of race further-and, therefore, racism and the scope of legal protection against it-the Rogers court likened the plaintiff's claim to ethnic identity in the wearing of braids to identity claims based on the use of languages other than Enghish. The court sought refuge in Garcia v. Gloor, a decision that upheld the general right of employers to prohibit the speaking of any language other than Enghish in the workplace without requiring employers to articulate a business justification for the prohibition. ${ }^{50}$ By excising the cultural component of racial or ethnic identity, the court reinforces the view of a homogenous, unicultural society, and pits blacks and other groups against each other im a battle over minimal deviations from cultural norms. Black women caimot wear their hair in braids because Hispanics cannot speak Sparnish at work. The court cedes to private employers the power of family patriarchs to enforce a nunibing saineness, based exclusively on the employers' whim, without the obhigation to provide a connection to work performance or busmess need, and thus deprives employees of the right to be judged on ability rather than on nnage or sound. ${ }^{51}$

Like Rogers, the Garcia case is a fascinating study of the extent to which antidiscrimination law perpetuates the allocation to employers of a kind of property right in the persons of women and minority employees. Out of business necessity, thirty-one of the thirty-nine employees of the company in Garcia were Hispanic because the population in the area served by the business was seventy-five percent Hispanic. Most of the employees were bilingual because many of the company's customers wanted to be waited on by a Spanish-speaking person. The employer prohibited employces from speaking Spanish on the job unless they were speaking to Spanish-speaking customers. Hector Garcia, a MexicanAmerican employee, was fired for responding in Spanish to a question from another Mexican-American employee about the availability of an

49. For further examples of cultural cooptation, see Williams, Metro Broadcasting, Inc. v. FCC: Regrouping in Singular Times, 104 HARV. L. REV. 525, 538 (1990).

50. Garcia v. Gloor, 618 F.2d 264, $267-69$ (5th Cir. 1980); cf. Gutierrez v. Municipal Court, 838 F.2d 1031, 1040-41 (9th Cir.), vacated, 409 U.S. 1016 (1988).

51. See Matsuda, Voices of America: Accent, Antidiscrimination, and a Jurisprudence for the Last Reconstruction, 100 YALE L.J. 1329 (1991). 
item requested by a customer. ${ }^{52}$ The use of Spanish is thus a virtue when the employer benefits, a vice when the employee does.

In Rogers, the court clearly considered the prohibition of all-braided hairstyles to relate more to American's choice of the image it would promote for its busmess than to planitiff's race, gender, or both. ${ }^{53}$ It noted American's assertion that "the pohicy was adopted in order to help American project a conservative, and busmess-like image," but made clear that the policy would have becn valid without the showing of any business justification. ${ }^{54}$

But what is American's conception of a busmess-like image? Why are American and Hyatt-top companies in the United States- afraid of black women in pageboy hairstyles? What role does sexuality play in determining the proper grooming and image of women? And should we distinguish between an einployer's fear and repression of black female sexuality and its exploitation of female sexuality im general, albeit a sexuality constructed to reflect proper notions of the ideally-bcautiful, sexual-but not sexy-woman? The busmess justification requirement dispensed with in Rogers is specially designed to assist courts in answering these questions. Properly apphied, this requirement should also assist the court in determining whether American's policy is inotivated by the complex of negative associations with black womanhood, associations that do not imitially appear to affect black nien or white women.

\section{TRuths AND SoJourns: STEReotyping AT THE INTERSECTION OF RACE AND GENDER}

\section{A. Of Changes and More}

1969. A picture of me in the family photograph album, standing in front of the law school, with cap and gown, sad-faced and sullen, displaying none of the joy that should be mine for my achievement. The mortar board sits atop my short-cropped Afro hairstyle, a style that I have adopted since my parents last saw me at Christmas and since I have obtained post-graduate employment that will begin after the bar exam. Since arriving in town for graduation, my mother has spoken of little else: Not only have I disgraced myself by chopping off my long,

52. Garcia, 618 F.2d at 266-68. The trial judge concluded that this was one of "a number of reasons that Garcia was fired." Id. at 267.

53. On the de minimis effect of American's policy, the court said that "this type of regulation has at most a negligible effect on employment opportunity .... It concerns a matter of relatively low importance in terms of the constitutional interests protected by the Fourteenth Amendment and Title VII ...." Rogers, 527 F. Supp. at 231.

54. Id. at 232-33. The court also minimized any psycloological abuse to the plaintiff as a result of the policy. American had indicated that the plaintiff could kecp her braids as long as she disguised them during working hours by wearing a hairpiece. To lier complaint that the hairpiece was uncomfortable, the court suggested that a larger lairpiece was in order. Id. at 233. 
thick hair, I also intend to aggravate my misdeed through the ludicrous juxtaposition of mortar board and nappy hair. Madame C. J. Walker ${ }^{55}$ will surely turn over in her grave. My younger sister has worn an Afro for almost a year, but $I$ would not be expected to stoop so low. $I$ will graduate at the top of my class, receive more honors than I know what to do with, and take a job that will surely bring prestige to my family, my law school, and my race. My hair undoes all of this, recalling for $m y$ mother her initial confusion over my decision to study law and now drawing public attention to her obvious failure as a parent for not having impressed upon me the importance of hair as a mechanism for survival. I might as well have been an "illegitimate" child.

Early 1970s. Another picture in the family album. My mother is beaming, smiling across a generation. She is looking down at my nephew, our family's first next-generation child, an out-of-wedlock legitimization of our eternal strength, hope, and survival. My mother is now beautifullyAfroed, and her smile is filled with pride, love, and understanding.

1985. In a few days I will teach in a four-day workshop for fifty black women. The participants have been chosen primarily because of their status in the corporate world of business and finance. My feelings of performance anxiety seem greatly overshadowed by feelings of happy excitement and expectancy at the prospect of navigating my peers through the murky waters of possibilities and pitfalls for black women in leadership positions. I arrive at the beauty parlor for the grooming of my hair, which, after a year in braids, has grown to my shoulders. Time is short and the hairdresser is late. When she arrives, on impulse, I decide to forgo braids and ask her to apply a chemical straightener to my virgin hair. I return to work a day later and the "significant other" of a male colleague addresses me in that chastising, condescending tone of voice reserved for slaves and women in domestic service: "Every time I see you, you've done something else to your hairl'"

Days later I arrive at the workshop site and greet the participants, my hair arranged in a style reminiscent of my former for-profit corporate self. Over the next four days, I am frequently complimented for my competence, unusual insights, and mastery of subject matter, but

55. See P. Giddings, When and Where I EnTER: The Impact of Black Women on RACE AND SEX IN AMERICA 187-89 (1984). Madame C.J. Walker, born Sarah Breedlove in 1867, was the first black female millionaire in the United States. She nuade her fortune selling hair products-particularly hair growers and straighteners-for black women. She also redesigned the hot comb for use by black women to straighten their hair. She ultimately established factories, laboratories, and training sehools, employed thousands of black women around the world, and made possible the employment and sinall busimesses of many more. Madame Walker remains a controversial fignre in black history, however, because some have attributed her success to the desire of black women for "straight, Caucasian-type hair," and others have adhered to Madame Walker's assessment focusing on "cur[ing] scalps when they were in a frightful condition." Id. at 188 . Whether she or her chicnts were concemed with straight hair, they surely were concerned with the length of hair. For exaniple, her company's 1924 yearbook described her hair products: "[M]any persons who lad less than a finger's length of hair when they began using it, their hair grew sixteen inches in less than three years [and] the products improved the scalps of persons . . . whose hair was short and stubby all their hives." Id. at 188-89. 
mostly-especially from those who over the years have watched me alternate between closely-cropped Afros and short, straight bobs-for the beauty of my long, straight hair.

\section{B. Hair and the Timeless Search for Legitimacy}

Hairstyle choices are an important mode of self-expression. For blacks, and particularly for black women, such choices also reflect the search for a survival mechanism in a culture where social, political, and economic choices of racialized individuals and groups are conditioned by the extent to which their physical characteristics, both mutable and immutable, approximate those of the dominant racial group. Hair becomes a proxy for legitimacy and determines the extent to which individual blacks can "crossover" from the private world of segregation and colonization (and historically, in the case of black women, service in another's home) into the mainstream of American life.

Black women bear the brunt of racist intimidation resulting from western standards of pliysical beauty. This intimidation begins early in the lives of black female children, continues througliout adulthood, and causes immeasurable psychological injury and dignitary harm. Such intimidation also is a crucial instrument to limit the economic and social position of black wonen. 56

Among distimct physical characteristics associated with race-skin color, hair texture, size and sliape of nose and mouth, and posterior nuusculature-skin color and hair texture are most often the focus of popular attention. And hair, without regard to skin color, has a history all of its own. Indeed, one may argue that hair texture, rather than skin color, determines racial classification. ${ }^{57}$ The reason for this singular focus on hair is not readily apparent, but the answer clearly falls outside the province of niere difference.

Unlike skin color and other physical manifestations of race, hair has both nuutable and immutable characteristics. Change in the nuutable and in the appearance of the immutable characteristics of hair can be accomplished with relative ease, albeit, for niany blacks, not without long-term consequences. Hair can be cut off, straiglitened out, curled up, or covered over either in the exercise of imdividual preference or to coniply with the tastes or preferences of others. The urnqueness of hair aniong plysi-

56. See P. Cobbs \& W. Grier, Black Rage 39-54 (1968); M. Washington, Black-Eyed Susans, Midnight Birds: Stories By and About Black Women xiv-xvii (M. Washington ed. 1990).

57. See In the Bronx, an Amerasian Finds His Roots, N.Y. Times, Oct. 10, 1990, at B1, col. 1 (describing orphan of Vietnamese mother and black American father, who had combed his hair to make it straighter in an effort to avoid racial prejudice in Vietnam and in the Umited States). 
cal characteristics correlating with race hes not only in the ability of its true nature to be disguised, but also in its susceptibility to external control.

Because the appearance of hair and soine of its characteristics are capable of change, the choice by blacks either to inake no change or to do so in ways that do not reflect the characteristics and appearance of the hair of whites, represents an assertion of the self that is in direct conflict with the assumptions that underhe the existing social order. Such selfassertions by blacks create fear and revulsion in blacks and whites alike. $^{58}$

During the 1960s, in the midst of the violent upheaval and the rapid social change that characterized that period, many blacks chose to wear "natural" or Afro hairstyles as a celebration of self-esteem, a rejection of the shackles of racist oppression, or a claim to cultural identity. Those who chose Afro hairstyles faced stiff opposition, similar to the opposition that today confronts those who choose braids, including the loss or refusal of einployinent. In the case of black women, few escaped inplicit associations among full Afro hairstyles, unpopular pohtical views, and uncontrolled and dangerous sexuality, growing out of national inedia coverage of the hunting down and subsequent trial of the activist and scholar Angela Davis.

Today, Afro hairstyles-or at least some of them-are widely accepted in all forms of employment, although the extent of their legal protection is far froin certain.59 They are considered by inany to reflect personal style - aesthetic choice-and are not generally associated with the politics of the period of their origin. However, the rationalizations that accompamied opposition to Afro hairstyles in the 1960s-extreine, too unusual, not businesslike, inconsistent with a conservative image, un-

58. Some black institutions prohibit their employees to wear braided hairstyles. Job counsellors at traditionally black colleges often advise students to avoid African-influenced styles when seeking employment. See Shipp, supra note 3, at C14; see also infra text accompanying notes $87-92$ (transmission by blacks of the culture of prejudice based on hair texture and skin color).

59. For cases upholding the right to wear Afro hairstyles, see Jenkins v. Blue Cross Mut. Hosp. Ins., Inc., 538 F.2d 164 (7th Cir. 1976); E.E.O.C. Dec. No. 72-0979, 4 Fair Empl. Prac. Cas. (BNA) 840 (Feb. 3, 1972). Note, however, that in Rogers, in drawing a distimction between Afro and braided hairstyles, the court imtimated, but stopped short of stating with any conviction, that Afro hairstyles are legally protected. Rogers, 527 F. Supp. at 232 . Also, even if protected from categorical exclusion, it is not clear whether and to what extent Afro hairstyles may be subjected to different regulation. For example, courts permit employers to establish different hair length regulations for men and women justified by commonly accepted gender-based social norms. See infra note 62. It is not clear, however, whether courts would permit employers to prohibit blacks from wearing a long or "big" Afro hairstyle such as the one associated with Angela Davis on the ground that only short Afro hairstyles are appropriate business attire. Finally, although the term "Afro" may advert to a particular natural hairstyle popularized in the 1960 s, the great variety of natural hairstyles contemporarily worn by blacks are not subsumed under the term "Afro." 
professional, inappropriate with business attire, too "black" (i.e., too militant), unclean-are used today to justify the categorical exclusion of braided hairstyles in many parts of the workforce, particularly in jobs that are either traditionally conservative or highly structured, involve close immediate supervision, or require significant contact with the public. ${ }^{60}$

\section{In Whose Image? The Application of Antidiscrimination Principles to Employer Grooming and Image Preferences}

By focusing on neutrality, immutability, and the exercise of fundamental rights, the Rogers court obscured an underlying principle in the application of antidiscrimination law to a variety of employer image preferences, including - but not limited to-those expressed through grooming codes. A careful analysis of cases in this area reveals that courts pay close attention to the eradication of stereotypes, attention in no way evidenced in Rogers. These cases also make clear that stereotyping is impermissible whether or not the standards set forth in Rogers are satisfied.

1. The Appeal to Willingham v. Macon Telegraph Publishing Co. The Rogers court's minimal scrutiny of American's pohicy derives in part from its rehance on Willingham v. Macon Telegraph Publishing Co., ${ }^{61}$ an en banc decision of the Fifth Circuit that upheld the denial of a male plaintiff's challenge to an employer's rule that barred men, but not women, from wearing longer than shoulder-length hair. ${ }^{62}$ Although the rationale of Willingham is far from clear, its conclusions have been widely adopted. ${ }^{63}$ Nonetheless, rehiance on Willingham, without more, greatly understates the extent to which employer image preferences have been found to violate protections against employment discrimination. A

60. See Shipp, Are Cornrows Right for Work?, EsSENCE, Feb. 1988, at 109.

61. 507 F.2d 1084 (5th Cir. 1975).

62. Willingham provides:

Distinctions in employment practices between men and women on the basis of something other than immutable or protected characteristics do not inhibit employment opportunity in violation of [Title VII]. Congress sought only to give all persons equal access to the job market, not to limit an employer's right to exercise his informed judgment as to how best to run his shop.

Id. at 1092. The case is cited not only for its support of an employer's right to establish grooming standards but also for its limitation on the "plus" theory of discrimination-typically conceived of in gender terms-to characteristics in addition to immutable traits, which bear on the exercise of a fundamental right. See supra note 37.

63. See Barker v. Taft Broadcasting Co., 549 F.2d 400 (6th Cir. 1977); Earwood v. Continental Southeastern Lines, Inc., 539 F.2d 1349 (4th Cir. 1976); Fagan v. National Cash Register Co., 481 F.2d 1115 (D.C. Cir. 1973). 
mechanical application of Willingham in Rogers is, therefore, misguided.64

A significant body of authority, not considered in Rogers, finds a violation of antidiscrimination law in the application of grooming codes and certain other einployer rules ${ }^{65}$-especially in cases that involve woinen as plaintiffs. ${ }^{66}$ These cases are perhaps best explained by the fact that courts recognize the reality of wornen's employment disadvantage. Notwithstanding the gender-neutral terms of antidiscrimination law, the distribution of einployinent advantages between inen and woinen is not symmetrical with regard to everything ranging from initial access, to occupational distribution, to enjoyinent of the economic and psychic benefits of work.

Not all courts have been content, therefore, to rest their decisions on grounds of neutrality, inutability, or fundanental rights-the justifications central to Rogers. 67 Rather, they have based their decisions on the prohibition of economic, psychological, and diguitary imjuries to women growing out of deineaning stereotypes regarding feinale characteristics, abilities and roles in society, prejudicial notions about female attractiveness, and the use of female sexuality for business advantage. ${ }^{68}$ Where such mjuries are apparent, courts have not required woinen to relinquish control over their physical images or other senses of themselves in the service of an employer's desired business image.

Thus, for example, a policy that prohibits inen, but not women, froin wearing longer than shoulder-length hair is not treated in the same way as a policy that prohibits a married woman from using her unınar-

64. See, e.g., Allen v. Lovejoy, 553 F.2d 522 (6th Cir. 1977) (rejecting the employer's attempt to apply Willingham principles to a policy prohibiting married women from using other than their husband's surnames even though the choice of name is neither immutable nor critical to the right to marry).

65. It is easy, even tempting, to make too much of the fact that a particular practice can be characterized as a grooming regulation. Decisions in cases such as Rogers should not be understood solely in comparison with eases involving grooming codes, but in relation to a wide variety of practices imvolving sociocultural associations. In addition, too much emphasis can also be placed on distinguishing cases such as Rogers from those that involve overt disparate treatment of all women compared to all men, see Carroll v. Talman Fed. Sav. \& Loan Ass'n, 604 F.2d 1028 (7th Cir. 1979), or a subgroup of women compared to a similarly situated subgroup of men. See supra notes $37 \& 62$ ("plus" discrimination). An essential element underlying all of these cases is a focus on demeaning stereotypes that affect employment opportunity either because they keep women out of work, represent them to the public as inferior workers, or compromise women's private choices in a way that reduces their enjoyment of work and life by disrespecting their diguity.

66. See Gerdom v. Continental Airlines, Inc., 692 F.2d 602, 605-10 (9th Cir. 1982); Carroll v. Talman Fed. Sav. \& Loan Ass'n, 604 F.2d 1028 (7th Cir. 1979); Laffey v. Northwest Airlines, Inc., 567 F.2d 429, 439 n.24 (D.C. Cir. 1976), cert. denied, 434 U.S. 1086 (1978); EEOC v. Sage Realty Corp., 507 F. Supp. 599, 607-11 (S.D.N.Y. 1981).

67. Rogers, 527 F. Supp. at 231.

68. See supra note 66 . 
ried surname. ${ }^{69}$ A married woman's choice of surname, like a black woman's choice of hairstyle, is associated in the minds of the women themselves and others with an extension of the personality, a dignitary interest. Both are related only indirectly to the exercise of a fundamental right or to the existence of an immutable trait. Limits on either choice in the context of employment are associated with stereotypical notions of the proper place in society for married woinen in general or black women in particular. Like the wearing of Afro or braided hairstyles, a married woman's choice to retain her unmarried surname may be considered a political act.

Reliance on Willingham further suggests that courts have drawn a bright line between immutable characteristics and historical or sociocultural associations witl race or gender, and that such distimctions sliould properly determine the scope of legal protection. Stereotypes about women and blacks carry overt and subliminal messages about the proper relationship of racial and gender groups in society. This function is served no less well by myths and distorted images unrelated to race or gender-speeific characteristics than by those related to immutable traits. The better-reasoned decisions avoid resting on this distinction. ${ }^{70}$ Indeed, stereotypes arise most often not from immutable traits but froin negative associations with those traits. These associations are used to reinforce the notion that individuals and groups possessing such traits are intellectually, morally, and culturally inferior to members of the dominant group. Antidiscrimination law should be, and at its best is, directed toward the behavioral manifestations of such negative associations, not to line drawing based on fixed, immutable, and outmoded conceptions of race or gender. Concepts such as immutability and neutrality are important tools of legal analysis, but they must be used to facilitate, not to preclude, the analysis of discrimination.

2. Image Discrimination in the Airline Industry. The fact that the Rogers case was brought against a major airline is itself of considerable significance. The airline mdustry's history of discrimination against women is nothing short of malevolent. ${ }^{71}$ Perhaps no industry has fought as liard to control its image and to seek competitive advantage by exploiting stereotypical cultural attitudes concerning the pliysical appearance,

69. See Allen v. Lovejoy, 553 F.2d 522 (6th Cir. 1977).

70. See, e.g., Phillips v. Martin Marietta Corp., 400 U.S. 542 (1971) (einployer refused to accept applications froin woinen with pre-school age children).

71. See generally Binder, Sex Discrimination in the Airline Industry: Title VII Flying High, 59 CALIF. L. Rev. 1091 (1971); see also Pouncey, Hers: Airlines Aren't Sexy Anymore, But They Still Fly, N.Y. Tïnes, Mar. 10, 1988, at C2, col. 1 . 
proper place in society, and supposed personal characteristics of blacks and woinen.

The industry's practices have invariably involved discrimination on the basis of woinen's physical presence and image. The airlines once systematically derried women in public contact positions the right to be "short, plump, . . . inyopic, married, imiddle-aged or a nother . . .."72 Men were excluded from these positions for no other reason than inaleness. The image that the airlines sought to portray in selecting its female employees was that of a chorus line: every inember female; every member young and nubile; and every nember in her own right a potential or actual beauty queen.

Of necessity, this image control has been sought most often for job categories that regularly bring employees into contact with the public. The basis of the right asserted by the airlines has varied from assertions of a correlation between gender and job perfornance, to employer prerogative, or to customer preference. Any distmction along these grounds has generally been found to be illusory. The carriers not only engaged in the most blatant discrimination against women, they flaunted it-defending their practices on the ground that few other industries equalled the industry's record in the number of women hired. ${ }^{73}$ Decades of hitigation

72. Pouncey, supra note 71, at C2, col. 1 .

73. In one of the most celebrated employment discrimination cases ever to be litigated, major air carriers sought to impose a requirement for "femaleness" on the job category of stewardess (now renamed flight attendant). Relying on the expert testimony of psychologists, Drs. Eric Berne and Raymond Katzell, and the experiential testimony of officials of Pan American, United Air Lines, and Eastern Air Limes, Pan American sought to justify the policy of excluding men from the job of flight attendant on the ground that the ability to perform satisfactorily the nonmechanical and essentially nurturing functions of the job was unique to women. Diaz v. Pan Am. World Airways, Inc., 311 F. Supp. 559 (S.D. Fla. 1970), rev'd, 442 F.2d 385 (5th Cir.), cert denied, 404 U.S. 950 (1971). Thus, air carriers sought not only to establish that airline passengers preferred female flight attendants, but also that a sound "scientific" basis existed for such preferences. For a critique of the return of "scientific" bases for discrimination, see D. NELKIN \& L. TANCREDI, DaNGerous Diagnostics: The Social Power of Biological information (1989).

In overturning the district court's decision upholding the industry's female-only hiring policy, the Fifth Circuit concentrated on sctting forth the legal standard for maintaining the bona fide occupational qualification exception to Title VII, an exception that permits an employer to limit employment in a particnlar job category to the members of one sex, national origin, or religious group in certain circumstances. (Under the language of Title VII, race cannot be the basis of a bona fide occupational qualification exception.) Notwithstanding Pan Am's attempt to characterize its claim in terms of a woman's urique ability to perform the job in question, the court could not lielp noting an important motivating factor underlying the industry's female-only hiring policy: the provision of an in-flight environment "enhanced by the obvious cosmetic effect that female stewardesses provide ...." Diaz, 442 F.2d at 388.

More than a decade after courts struck down the industry's female-only policy, Southwest Airlines again attempted to exclude males from the job of flight attendant, this tine recasting the industry's earher female-only preference in straightforward ecouomic terms based on Southwest's claim of competitive advantage for itself vis-a-vis other airlines, supported also by appeals to customer prefer- 
were required to begin breaking down discriminatory patterns that involved unequal pay, ${ }^{74}$ and discrimination against married women, ${ }^{75}$ followed by discrimination against pregnant women. ${ }^{76}$ The battle continues in the form of contests over maximum weight requirements for women that are set at levels that perpetuate stercotypes about female attractiveness and often impose unnecessary health risks on women ${ }^{77}$ and mandatory use of cosmetics. ${ }^{78}$

This longstanding chorus-line image for female airline einployees has necessarily had a disparate impact on black women. Although the airlines first atteinpted to disguise their sexually discriminatory policies by poimting to the number of women in their employ, no such justification could have explained the near-total exclusion of black women. ${ }^{79}$ As with other fainous chorus lines, ${ }^{80}$ the presence of black women posed a threat not only to the airline industry's sense of beauty and symmetry, but also to the presumed sensibilities of airline customers. ${ }^{81}$ Two distinct stereotypes of female sexuality exist: one white and one black-one

ence. See Wilson v. Southwest Airlines Co., 517 F. Supp. 292 (N.D. Tex. 1981). Nevertheless, despite some evidence that the image of sexy females had played some part in Southwest's success, the court stuck to the strict standard set forth in Diaz Id.

74. Laffey v. Northwest Airlines, Inc., 366 F. Supp. 763 (D.D.C. 1973), modified, 374 F. Supp. 1382 (D.D.C. 1974), aff'd in part, vacated and remanded in part, 567 F.2d 429 (D.C. Cir. 1976), cert denied, 434 U.S. 1086 (1978).

75. See Sprogis v. Umited Air Lines, Inc., 444 F.2d 1194 (7th Cir. 1971); Cooper v. Delta Air Limes, Inc., 274 F. Supp. 781 (E.D. La. 1967); Neal v. American Airlines, EEOC Dec., Case No. 6-65759, Einpl. Prac. Guide (CCH) ๆ 6002 (1968).

76. Compare Harriss v. Pan Am. World Airways, Inc., 649 F.2d 670 (9th Cir. 1980) (policy requiring commencement of leave upon pregnancy justified by safety considerations) with Burwell v. Eastern Air Lines, Inc., 633 F.2d 361 (4th Cir. 1980) (policy of mandatory pregnancy leave during first 13 weeks violated Title VII rights for flight attendants), cert. denied, 450 U.S. 965 (1981).

77. See Gerdom v. Continental Airlines, Inc., 692 F.2d 602 (9th Cir. 1982).

78. See Airline Retracts Rule Requiring Makeup Use, N.Y. Times, May 16, 1991, at A19, col. 1.

79. The first stewardesses were employed on a commercial fight in 1930, over the strenuous objections of male pilots and company managers. Binder, supra note 69, at 1101. The first black stewardess in U.S. commercial aviation was employed by Mohawk Airlines in 1958. B. LANKER, I Dream a World: Portraits of Black Women who Changed America (1980).

80. See Lambert, Rockettes and Race: Barrier Slips, N.Y. Times, Dec. 26, 1987, at B25, col. 5 (describing the hiring of the first black Rockette). The Rockettes are a more than 60 year-old institution in New York City, a symbol of New York City's Radio City Music Hall and of the nation. Russell Markert, founder of the Rockettes, reportedly forbade a suntan on a white dancer because "it would inake her look like a colored girl." Id. at B27, col. 1. During the early 1980s, the director of the Rockettes, Violet Holines, defended the racially-exclusionary policy on artistic grounds, noting that "[o]ne or two black girls in the line would definitely distract. You would lose the whole look of precision, which is the hallmark of the Rockettes." Id; see also P. WILLIAMs, THE ALCHEMY OF RACE AND RIGHTS 116-118 (1991).

81. Employer arguinents about customer preference often lack empirical basis. See Binder, supra note 71 , at $1104 \mathrm{n} .80$ (casting suspicion on argnments that the airlime industry's no-marriage rule for stewardesses was based on customer preference by citing surveys indieating that $80 \%$ of 25,000 passengers had no preference regarding the inarital status of stewardesses). The customer preference argument in Wilson v. Southwest Airlines Co., 517 F. Supp. 292 (N.D. Tex. 1981), failed 
good, innocent, and pure; the other sinful, evil, carnal, and taboo. ${ }^{82}$ Airlines could profitably titillate white male travelers with one but not the other. Thus, the practice of excluding black women from female-identified jobs involving public contact was to be expected as nothing more than a continuation of the portrayal of the patriarchal ideal of Victorian white wornanhood, of woman as a sex object, but not sexy.

\section{Public Degradation of Black Women}

Many employers express shock that black women who refuse to unbraid their hair take such a strong stance, one that could cost them their jobs, in defense of a hairstyle. More shocking is the recurrence among unrelated employers of virtually identical solutions to the issue of braids, solutions that embody overt racist caricatures of the past expressed in the subtle, symbolic code of contemporary racism. Invariably, black woinen are told either to unbraid their hair or to disguise their braids by pulling them into a bun or cover them up with a wig or hairpiece. ${ }^{83}$ This latter solution-the forcible covering up of a black woman's hair-connotes a demeaning servitude that persists even in the face of changes in one of America's most cherished and enduring symbols. For the first tine in the more than one hundred years of the Aunt Jemima trademark's existence, its current owner has deemed it profitable to reveal Annt Jemima's hair. ${ }^{84}$ But for the color of her skin, the new Annt Jemima could pass for

to some extent because of the inconclusive nature of data on the question of customer preference for sexy stewardesses.

82. See, e.g., EEOC Dec. No. 70-90, Aug. 19, 1969 (notation on employment application that black woman was not hired as a flight attendant because slie was too ugly and had big lips); see also Omlade, Hearts of Darkness, im Powers of Desire: The Politics OF SEXuALITY 350, 352 (1983).

83. In Rogers, as if to mitigate the effect of its loolding on black women, the court noted that "[in]oreover, the airline did not require plaintiff to restyle lier hair. It suggested that slie could wear her hair as slie liked while off duty, and permitted her to pull her hair into a bun and wrap a hairpiece around the bun during working lours . . . . Plaintiff lias done this, but alleges that the hairpiece has caused her severe headaches. A larger liairpiece would seem in order." Rogers, 527 F. Supp. at 233; see also Shipp, supra note 3, at 14 (CheryI Tatuin told to pull her braids into a bun to comply with Hyatt's dress code); Wheeler, Hotel Worker Fights to Keep Cornrows: J.W. Marriott Supervisors in D.C. Call Hair Style Too Extreme, Wash. Post, Jan. 5, 1988, at D3 (Marriott Hotel's Director of Corporate Relations said that black women eunployees with braids liad "agreed" to wear wigs to work). A similar suggestion was made in Carswell v. Peachford Hosp., 27 Fair Empl. Prac. Cas. (BNA) 698 (N.D. Ga. 1981) (1981 WL 224). There, lowever, the suggestion was made for safety rather than aesthetic reasons.

84. See Campbell, A Battered Woman Rises: Aunt Jemima's Corporate Makeover, The Village Voice, Nov. 7, 1989, at 45. Actually, the wearing of headwraps annong African and black American women has botli functional and cultural significance, at least when done voluntarily. See A. Simkins, The Functional and Symbolic Roles of Hair and Headgear annong Afro-American Women: A Cultural Perspective (1982) (unpublislied doctoral dissertation) (available from autlior). Like the braiding of hair, the wearing of headwraps lias been a constant cultural practice among black women wherever they exist in the world. However, the cultural significance of this practice liad been perverted in the minds of blacks and whites alike by race-gender stereotyping. Depictions of black 
Betty Crocker. There is nothing wrong or offensive about the similarity of these trademarks, but the marketing judgment of Aunt Jemina's owner does reflect the assumption that the public equates progress for black women with the imitation of white women. Because being black is an occasion for oppression, avoiding blackness and its attached cultural associations becomes the essential mechanism of hiberation.

Initially, black wonien who are permitted to break through the barrier of racial exclusion into "visible" jobs involving public contact are likely to be those who possess physical characteristics close to those of women of the dominant racial group. ${ }^{85}$ Notions about the black wonian's presence that were prevalent during periods of overt racism and exclusion are now subsumed in the symbolisn that cliaracterizes contenporary racism. Rather than focusing on the black woman herself, the impetus to exclude is transferred to the black woman's hair, first in its natural state in the form of Afro hairstyles, and then to the black wonıan's culture as reflected in braided or so-called "artificial" hairstyles. ${ }^{86}$

The writings of black women confirm the centrality of hair in the psychological abuse of black women. ${ }^{87}$ Virtually all novels and autobiographical works by black woinen writers contain sonie treatinent of the issue of discrimination against black women because of skin color and hair texture. Maya Angelou relates her childhood fantasy that she would awaken from her black and ugly nightmare to discover and reveal to others her true self: a blond-haired, blued-eyed beauty who, like a true "Cinder Ella," had been turned into an ugly black girl by her cruel stepnıother. ${ }^{88}$ Gwendolyn Brooks' fiction describes an unbridgeable space

woinen with covered heads typically denote servitude, and early depictions of Aunt Jemina show her not only with covered head but also with exaggeratedly black skin, bulging eyes, a wide mouth, large red hips, and oversized teeth. These exaggerations reinforce the notion that blacks, especially black women, symbolize ugliness, and that the black woman's ugliness justifies her servitude.

85. See Whitt, Temporary Agencies Mask Bias with Color Codes, Atlanta Const., Dec. 15, 1989, at A22 (describing the use of code words by employees and temporary employment agencies to fill overtly discriminatory job orders).

86. Black women were hired in some jobs that brought them into contact with the public but only in menial positions where their subordination was clear. See G. LERNER, BLACK WOMEN IN WhITE AMERICA 321 (1972); see also Terrell, A Colored Woman in a White World, reprinted in BLACK WOMEN IN WHITE AMERICA 333-37, and Terrell, What it Means to be Colored in the Capital of the United States, reprinted in BLACK WOMEN IN WHITE AMERICA 378-82.

87. In Rogers, the court set a very high standard of psychic injury, one that arguably applies in cases in which the plaintiff's claim is based on the presence of a hostile working environment, but not in cases involving clearly ascertainable economic injury resulting froun dismissal or refusal to hire. It did so by analogizing to the standard set by the Fifth Circuit in Garcia v. Gloor, 618 F.2d 264 (5th Cir. 1980), a case upholding an einployer's right to disıniss an einployee for speaking Spanish; the holding in Garcia has been undermined by subsequent decisions. See supra note 48 and accoinpanying text.

88. See M. Angelou, I Know Why The Caged Bird Sings (1969). 
between a black woman and her husband, ${ }^{89}$ created by the wife's lack of light skin and long hair. Through poetry, Brooks celebrates her sisters who have retained their Afros. Alice Walker frees herself from the "oppression of oppressed hair, a ceiling on the brain, a last barrier to spiritual liberation." 90 And in her classic, The Bluest Eye, Tom Morrison describes the insidious ways that young black girls learn to hate themselves-by observing the reaction of adults (mcluling black ones) to light-skinned female children with "good" hair. ${ }^{91}$

However, degradation of black women on account of their hair does not arise solely because some black women wear their hair in its natural state or in styles associated with African culture. Indeed, when most black women adhered to the dominant culture's grooming and hairstyle codes-when many black women sought eseape from grinding racist oppression by ritualistically straightening their hair-black women were disparaged because of their artificially straightened hair. The aesthetic standards of the white society-no matter how well-emulated-establish a boundary between black and white, good and bad, pure and evil, true and false, justifying not only the aesthetic or ideal of racial superiority, but also the social, economic, and political structures of domination that result from this ideal.

What links Afro or natural hairstyles and so-called "artificial" ones (such as braids), is a question of assimilation. Blacks who challenge the status quo, especially its dominant cultural manifestations, are identified as major threats to central national values. Those who do not exercise volition in favor of such values are seen as having the stereotypical characteristics commonly associated with black will and willpower-undis-

89. See Brooks, To Those Of My Sisters Who Kept Their Naturals Never to Look a Hot Comb in the Teeth, in CONFIRMATION, AN ANTHOLOGY OF AFRICAN AMERICAN WoMEN 84-85 (A. Baraka \& A. Baraka eds. 1983).

90. Walker, Oppression Puts a Ceiling on the Brain, in LIviNg By THE WORD 71 (1988).

91. See T. Morrison, The Bluest Eye 53-66 (1970). Describing the reaction of two "ordinary" young black girls to the taunts of Maureen Peal, "[a] high-yellow dream child with long brown hair braided into two lynch ropes," Morrison writes:

If she was cute- and if anything could be beheved, she was-then we were not. And what did that mean? We were lesser. Nicer, brighter, but still lesser. Dolls we could destroy, but we could not destroy the honey voices of parents and aunts, the obedience in the eyes of our peers, the slippery light in the eyes of our teaclers when the encountered the Maureen Peals of the world. What was the secret? What did we lack? Why was it inportant? And so what? Guileless and without vanity, we were still in love with ourselves then. We felt comfortable in our skins, enjoyed the news that our senses released to us, admired our dirt, cultivated our scars, and could not comprehend this unworthimess.... And all the time we knew that Maureen Peal was not tle Enemy and not worthy of such intense hatred. The Thing to fear was the Thing that made her beautiful, and not us.

Id. at 61-62; see also A. KenNedy, FunNyHOUSE OF THE NEGro: A PLAY IN ONE ACT (1969); M. Washington, supra note 56; Wolfe, The Hairpiece, in The COLORED MUSEUM 19-23 (1985). 
ciplined, insubordinate, unwilling to melt.92 Blacks are thus the cause of their low socioeconomic status rather than victims of that status. ${ }^{93}$

In the case of black women, assimilation also means the adoption of the ideals associated with true woinanhood. These ideals have their physieal and cultural manifestatious in the limitation of black women's choices relating to grooming, beautification, reproduction, and marriage. ${ }^{94}$

Notwithstanding the possible perpetuation of social distinctions between men and women, blacks and whites, it could be argued that courts properly accord great discretion to employers in setting grooming standards because of the de minimis effect such standards have on einployment opportunity. Einployees can either coinply or seek employment elsewhere. Moreover, soine would argue that black women's disadvantages in the labor market would not be lessened if black or all woinen were permitted to work as well as braid their hair. But whether to frame the issue in a case like Rogers as essentially one that involves grooming standards is itself a question of substantial political and legal significance, and ultimately determines the degree to which one considers einployinent rights to be affected.

Judgments about aesthetics do not exist apart from judgments about the social, political, and economic order of a society. They are an essential part of that order. Aesthetic values determine who and what is valued, beautiful, and entitled to control. Thus estabhished, the structure of society at other levels also is justified. What appears to be merely an aesthetic judgment in Rogers is part of the subordination of black woinen and is inextricably connected to the more obvious economic judgments reflected in other cases that affect black women. ${ }^{95}$

92. See A. Bloom, The Closing of the American Mind 91 (1989).

93. A focus on volition also supports the notion that the solutions to racism and sexism lie im the people wlio are their victims. However, prejudice and discrimination have hittle to do with the behavior of out-groups. Rather, they are the result of deeply-entrenclied structures in the society and in the social psycliology of individuals. Vices of subordinated groups become virtues of the dominant one. See G. SIMPSON \& J. YINGER, RACIAL AND CUlTURAL MINORITIES: AN ANALYSis of Prejudice AND Discrimination 99-101 (5th ed. 1985).

94. I do not mean that assimilation is necessarily bad or that all black people must or should retain a visual or other connection to black culture. I do mean to argue in favor of choices that include those associated with blackness. And I do mean to criticize the empty promise of economic and social elevation through assimilation to a dominant culture that does not permit or recognize contributions to the national culture so long as they are identified with blackness. This elevation denies its benefits to all but a token few blacks.

95. See supra notes 35-37. 


\section{The NATURe OF KINShiP}

The issues in Rogers defy resolution by resort to arguments about mere aesthetic judgments, doctrinal confusion, or minimal effect on employment rights. The apphication of Willingham in Rogers reflects patriarchal assumptions about women generally and competing stereotypical images about woinanhood determined by race. These competing images limit black woinen's choices in ways far inore fundamental than is readily apparent in controversies about hair. And although Willingham and Rogers appear to reserve to white women the privilege of their personal and cultural choices, these cases are based on stereotypes that constitute a ready inechamism for denying einployment opportunity to white woinen who refuse to express themselves in ways that satisfy their employers' notions of "white fernaleness." These decisions effectively lock men-black and white-and black woinen out of choices associated with "true" woinanhood; read in reverse, they lock white women into such choices. ${ }^{96}$

Much of the competition between ideologies about black and white woinanhood centers on questions of sexuality, beauty, and motherhood. Other comparisons stereotype black women as independent, coinpetent, worldly, and tough, and white women as dependent and infantile. These characteristics are not attributed to black women in any positive sensesuch as evidence of their successful adaptation to inultiple oppression of race, gender, and typically class, or as such traits would be viewed when associated with men of any color. Instead, the presence of these traits necessarily places black woinen outside of any definition of womanhood.

96. See, e.g., Hopkins v. Price Waterhouse, 490 U.S. 228 (1989); Craft v. Metromedia, Inc., 766 F.2d 1205 (8th Cir. 1985). Both cases involve sex discrimination based on physical image against women in upper-level employment. Craft was effectively "demoted" (albeit without loss of compensation or benefits) from co-anchor to reporter of a television news program. Craft claimed that the television station applied a standard of good grooming to male and female co-anchors in an uneven way by requiring her to conform to a stereotypical image of how a woman should appear. She further alleged that she was told that she was being reassigned because the television audience "perceived her as too old, too unattractive, and not deferential enough to men." Craft, 766 F.2d at 1209. The station reassigned Craft following a telephone survey of approximately 400 viewers im which the station asked them to rank Craft in comparison with female anchors at other stations. Four of the questions dealt with "good looks" and "the dress of and image of a professional anchor woman." Id. Initially the court had to decide whether to treat Craft's sex discrimination claim under standards governing grooming codes or those applicable to other types of employment discrimination cases. Id. at 1211

In Hopkins, Anu Hopkins was demied a partnership when several partners of her accounting firm commented on her candidacy by describing her as "macho," claiming that she "overcompensated for being a woman," and recommending that she "take a course at charm school." 490 U.S. at 235. When Hopkins' candidacy was placed on hold, the partner who advised her of this action recommended that she "walk more femiminely, talk more femininely, dress more femininely, wear makeup, have her hair styled and wear jewelry." Id. 
Black women are not only "defeminized," they are idealized as affirmatively masculine. 97 Thus, mythical views of femininity are constructed not only in opposition to white inaleness but also as a rejection of black femaleness. Women are therefore socialized to avoid life choices and behavioral characteristics associated either with white men or black women. ${ }^{98}$

Stereotypes about black inen also represent a confluence of negative images about race and gender. As black woinen are "defeminized" in relation to white women, so too are black inen "demasculinized" in relation to the ideal of inanhood represented by white inen. Black men are further "demasculinized" in relation to black women based on myths concerning the perversion by blacks of distributions of familial power and authority based on gender-a perversion that is the direct result of the absence of femaleness in black women. These notions typically lead to the development of policies directed toward alleviatimg the consequences of racism through the creation of a proper patriarchal balance between black inen and black women.

Stereotypes and negative images of black women serve many functions. They separate black and white women from each other, and limit all women's choices by perpetuating competing ideologies of womanhood based on race. ${ }^{99}$ They inake black women responsible for the economic and social position of black families in general and black inen im particular. Most important, they make black women mvisible. The black woman's invisibility serves to blind all women and all blacks to the interactive relationship betwecn race and gender, leads to the developinent of legal theories and social policies directed at either race or gender without fully considering the miphications of such theories and policies, and ultimately assures the perpetuation of domination on the basis of race and gender for all women and members of subordinated races.

\section{Healing the Shame}

Eliminating the behavioral consequences of certain stereotypes is a core function of antidiscrimination law. This function can never be ade-

97. See D. White, AR'N'T I A Woman? Female Slaves in the Plantation South 16667 (1985) (summarizing the views of social scientists who conclude that the result of slavery and discrimination has produced a kind of "studdism" and rigidity in black women and implying, to some extent, that black women are more masculine than black men).

98. This view underhies some of the justifications offered in support of the creation of acadermes for black males in urban school systems. See Hancock, Ujamaa Means Controversy: A Proposed AllBlack High School for Young Men Invokes Hope for Success and Fears of Segregation, Village Voice, Nov. 6, 1990, at 11; see also U.S. Judge Blocks Plan for All-Male Public Schools in Detroit, N.Y. Times, Aug. 16, 1991, at A19, col. 4.

99. See Singleton, supra note 19 , at 12-17. 
quately performed as long as courts and legal theorists create narrow, inflexible definitions of harm and categories of protection that fail to reflect the actual experience of discrimination. Considering the interactive relationship between racism and sexism froin the experiential standpoint and knowledge base of black women can lead to the developinent of legal theories grounded in reality, and to the consideration by all woinen of the extent to which racisin limits their choices as women and by black and other men of color of the extent to which sexism defines their experiences as men of subordinated races.

Creating a society that can be judged favorably by the way it treats the women of its darkest race need not be the work of black woinen alone, nor will black women be the exclusive or primary beneficiaries of such a society. Such work can be engaged in by all who are willing to take seriously the everyday acts engaged in by black women and others to resist racism and sexism and to use these acts as the basis to develop legal theories designed to end race and gender subordination.

Resistance can take the form of momentous acts of organized, planned, and disciplined protests, or it may consist of small, everyday actions of seeming insignificance that can nevertheless validate the actor's sense of dignity and worth-such as refusing on the basis of inferiority to give up a seat on a bus or covering one's self in shame. It can arise out of the smallest conviction, such as knowing that an old woman can transmit an entire culture simply by touching a child. Sometimes it can come from nothing more than a refusal to leave a grandinother behind. 